Available Online: https://proceeding.researchsynergypress.com/index.php/cset/index

RSF Conference Series: Engineering and Technology

ISSN 2809-6843 (Online) | 2809-6878 (Print)

Volume 1 Number 1 (2021): 225-233

\title{
Factors Affecting Agroindustry Development Etawa (PE) Breeding Goat Milk in Daerah Istimewa Yogyakarta
}

\author{
Dwi Aulia Puspitaningrum¹, Khoirul Hikmah², Adi Ilham ${ }^{3}$ \\ 1Department of Agribusiness, Faculty of Agriculture UPN “Veteran” Yogyakarta \\ 2Department of Management, Faculty of Economics and Business UPN “Veteran” Yogyakarta \\ 3Department of Chemical Engineering Faculty of Industrial Engineering UPN "Veteran" Yogyakarta
}

\begin{abstract}
The demand for animal food product in Daerah Istimewa Yogyakarta (DIY), the Special Region in Java, over the last ten years has shown a significant increase. This is in line with the increase in the population of DIY and also the increase in the income per capita of the people in DIY in meeting the adequacy of food sources of higher quality protein. One of the requests for animal food products other than meat is milk. The milk that is currently starting to develop apart from cow's milk is goat's milk, especially the type of goat's milk from Etawa Crossbreed (PE). This paper is the result of a research that aimed at analyzing the factors that influence the development of PE goat milk business in DIY, viewed from the supply and demand side. The analytical method used is descriptive with a simultaneous equation modeling approach. The results showed that simultaneously the variables of the population of PE goats, the amount of milk production of PE goats, the amount of milk production of PE goats in the year prior had an effect on the supply side. Meanwhile, on the demand side, simultaneously, the factors that influence the demand for PE goat milk are the population of DIY, income per capita, the price of PE goat milk and consumption of PE goat milk in the year prior. The study on the development of PE goat's milk business was carried out with a simple descriptive analysis showing that in the future the demand for PE goat's milk will increase, it is necessary to make efforts to strengthen the potential of PE goat's milk in DIY, especially in terms of milk products processing business and their derivative products. It is hoped that in the future PE goat's milk can play more role as a substitute product for cow's milk in DIY.
\end{abstract}

Keywords: Milk, Goat, Etawa Cross breeder, Demand, Supply, Potency,

\section{INTRODUCTION}

This is an open access article under the CC-BY-NClicense

Large livestock cultivation such as cattle, buffalo, horses, goats are very popular with people because they can be used as the main source of acquiring food needs of animal protein and have a high rupiah value. One of the big livestock that is popular is goat. Goats can be taken as a source of animal food product. Almost all types of goats can be taken by meat and some other types of milk can also be taken as a source of animal protein foods as well. One of the goat type that currently developing is a crossbreed Etawa Goat (PE). In Sleman Regency, there is a plateau area at the foot of the Merapi Mountains which is the center of cattle and goat farming. Etawa crossbreed in Sleman Regency is currently being sought by the Sleman Regency Agriculture Office in order to become a superior product, because it can increase the income of its people to become more prosperous and powerful.

One of the products of goat farm products is milk. Milk is a liquid from a healthy and clean cattle goat who is milked correctly and according to the direction (Meutia et al., 2016). From a livestock perspective, milk is the secretion of livestock milk glands that are currently lactating and well milking (Oka et al., 2017). Goat milk can be processed into various products (Febrina et al., 2019); Mahdiah (2020). Goat milk is one of the nutraceutical health drinks. Because goat milk is rich in minerals and vitamins and 
the creamy texture is used as a substitute of a supplement number consumed by people every day and easily digested than cow's milk (Lad et al. 2017). Besides helping the healing process of various diseases and maintaining physical health and maintaining strength, goat milk can also help increasing reproductive capacity, maintainingfetal growthand development, assisting the process of normallabor, and improving the quality of human breast milk, helping children in digestion and gaining weight, and also increasing immunity (Dewi, 2018).

In the past 5 years, especially in Sleman Regency, there has been an increase number in the development of PE goat milk, not only in liquid form but also in the form of powder (Sleman Agriculture Service, 2020). When the Covid-19 pandemic appeared, the PE goat agroindustry in Sleman Regency had decreased, but at the beginning of 2021 the request of PE goat's milk was both liquid and powdered as well as other variant product was gradually increasing. In order to maintain the conditions in this difficult time, there should be a strategy to maintain the business. In addition, PE goat agroindustry is required to understand what is desired and expected by the consumers to create consumer buying interest in PE goat dairy products. Therefore it is important for producers to implement marketing mix strategies.

The livestock sector is playing a significant a role in the development process, especially in rural areas. This is because there are still many needs thatcan be fulfilled independently in the field oflivestock, for example many animal feeds are taken from nature. Sleman Regency Livestock Sub-sector has the highest GRDP value among other agricultural subsectors but the growth rate each year cannot be higher than other sub-sectors(Puspitaningrum2020).LivestockSub-sectorisone of theforcesoftheagricultural sector. On the basis of the background mentioned above, the purpose of this study is to analyze factors that influence the demand and offer of PE goat milk in DIY, so the development potential of PE goat milk in the future can be seen. This research is integrated from upstream to downstream in order to produce a solution, it was started with PE probiotic goat milk products analysis, added value analysis associated with the potential mapping of PE goat agroindustry in Sleman Regency on the basis of geographic information systems (sig), and finished it with Requests and Offering PE goat dairy products factor analysis and the superior sector of Sleman Regency's role analysis which has never been done before.

\section{LITERATURE REVIEW}

\section{Ettawa Goat Cross breeder}

Dairy goats that are widely developed in Indonesia are usually crossbreed goats which are one of the original domestic animals and have high genetic potential as a dual-purpose producer, namely meat and milk (Dewi, 2018). The Ettawa goat is a good type of dairy goat and is also a meat producer. The fur color is based on white, black and brown. The ear length is $\pm 30 \mathrm{~cm}$. The male goat weighs about $91 \mathrm{~kg}$, and the female weighs about $63 \mathrm{~kg}$ (Maesya \& Rusdiana, 2018). According to Sutama (2011), Etawa goats are able to produce $2.5-3$ liters of milk per day.

\section{Marketing Mix}

The marketing mix is the set of controllable tactical marketing tools that a company uses to produce the response it wants in the target market. The marketing mix consists of 4 P's, namely product, price, place and promotion. A product is anything tangible or intangible that is offered for consumption or in the form of a service, experience or idea. Price is the money charged for a product or service or the amount and value that customers exchange for the benefit of owning or using a product or service (Kotler \& Armstrong, 2012). Promotional activities are not only functioned as a communication tool between companies and consumers, but also to influence consumers in purchasing activities according to their wants and needs (Sartika \& Hellyward, 2017). Location is the place where a business is carried out. An 
important factor in the development of a business is the location of urban areas, how to get there and how long the duration is to get to the location (Swastha Basu \& Irawan, 2008).

\section{Demand Analysis}

Demand is the amount of goods or services at various price levels that consumers are willing, wanting or being able to buy within a certain period of time. According to Hysocc (2013), demand is the amount of goods purchased or requested at a certain price within a certain period of time. Meanwhile, Ritonga (2003), suggests demand is the amount of goods or services purchased at various price levels. Demand is closely related to the satisfaction of consumer desires for goods and services, and consumers' demand for goods and services is not limited. The elements contained in demand are goods or services, prices and conditions that affect them. Meanwhile, commodity demand refers to the quantity demanded at a certain price level, so Demand is the desire of consumers to buy goods at different price levels within a certain period of time. (Fildaus, 2009). The main analysis of demand theory is the relationship between the goods' demand and the price of the goods themselves (Fittresdy et al., 2014). So, if the price is higher, the demand will decrease, and vice versa (Hanafi \& Rochaeni, 2014).

\section{Supply Analysis}

Supply is a good or service provided by producers to consumers at a certain price level and period of time. In addition, the price and the quantity supplied are positively correlated. If the price increases, the quantity supplied of goods increases, and vice versa. According to Yoeti (2008), the consequence of the law is that if the price of goods or services increases while other prices remain constant, then the amount of goods and services produced by producers is often much greater than the amount of goods or services. The theory of supply uses the principle of ceteris paribus, which is a condition in which other factors are held constant.

\section{RESEARCH METHODOLOGY}

This research uses descriptive exploratory research method with simultaneous equation modeling approach. Explorative descriptive is a research method to study, to analyze and to describe the various links and relationships of the object with the phenomena that occur and finally to gain conclusions that are obtained from the studies conducted (Kerlinger, 2007). The data used in this research are primary and secondary data. The main secondary data comes from the Indonesian Livestock Statistics Data as well as the latest SUSENAS data released by BPS. Meanwhile, field observation data came from all business actors based on Ettawa crossbreed goat milk (PE) starting from the upstream side, namely Ettawagoatbreeders, all Ettawa goat milk marketplayers, Ettawagoatmilkagro-industry entrepreneurs, as well as provincial and district/city governments. Data were collected by means of direct interviews and visits and direct observation. Data collection techniques were carried out by triangulation techniques which included secondary data analysis, semi-structural interviews with observed respondents, group discussion forums (FGD) and direct observation in the field to statistical laboratory tests and data processing. Technical analysis of the data were used to determine the factors that influence the demand and supply of PE goat's milk in DIY using a simultaneous model analysis with 2 SLS (Two Stage Least Square) technique. Meanwhile, the model estimation was assisted by Eviews 8 software.

To solve the equation in simultaneous form, the equation must first be identified, with the following criteria:

$\mathrm{K}-\mathrm{k} \geq \mathrm{m}-1$. if obtained $\mathrm{K}-\mathrm{k}=\mathrm{m}-1$, then it is determined to be just identified , 
if $\mathrm{K}-\mathrm{k}>\mathrm{m}-1$ is called over identified $\mathrm{d}$. And if it is obtained $\mathrm{K}-\mathrm{k}<\mathrm{m}-1$ it is determined to be under identified.

Where: $\mathrm{K}=$ Number of exogenous variables in the model

$\mathrm{k}=$ Number of exogenous variables in the structural equation $\mathrm{M}=$

Number of endogenous variables in the model

$\mathrm{m}=$ Number of endogenous variables in the structural equation

The Hypothesis Testing with $\mathrm{F}$ test (joint) and T test (partial) and also the Classical Assumption Deviation Test and Goodness of FIT test: Multicollinearity: Coefficient of Determination (R2) and F Value; and through the Durbin-Watson value(Autocorrelation)

\section{FINDING ANDA DISCUSSION}

Analysis of 2SLS Method in order to Obtain Variable Reduction Equation of PE Goat Milk Price (HSK)

Table1.Analysis of2SLSMethodin order to Obtain Variable Reduction Equation of PEGoat MilkPrice (HSK)

\begin{tabular}{|c|c|c|c|}
\hline NOTATION & VARIABLE & $\begin{array}{l}\text { COEFFICI } \\
\text { ENT }\end{array}$ & $\begin{array}{l}\text { STD } \\
\text { ERROR }\end{array}$ \\
\hline $\mathrm{C}$ & Constant & $-52377,2$ & -0.456789 \\
\hline PROD & PE Goat Milk Production & $0,607.809$ & 0,008791 \\
\hline POP & Total PE Goat Population & 0,234870 & 0,040287 \\
\hline HSK & PE Goat Milk Price & 0,143261 & 0,023041 \\
\hline JKM & Number of PE Goats Entering DIY & 0,241351 & 0,074912 \\
\hline JKK & Number of Goats PE Exiting DIY & $-0,176080$ & 0,032726 \\
\hline PROD $_{\mathrm{T}-1}$ & PE Goat Milk Production in Year Prior & $-0,043416$ & 0,042831 \\
\hline KONS & Consumption of PE goat's milk & 0,006392 & 0,002708 \\
\hline PEND & DIY's Population & 0,043416 & 0,042831 \\
\hline PKAP & DIY's Per capita Income & 0,006392 & 0,002708 \\
\hline HSS & DIY's Cow Milk Price & $-0,208438$ & 0,171501 \\
\hline \multirow[t]{3}{*}{$\mathrm{KONS}_{\mathrm{T}-1}$} & $\begin{array}{l}\text { Consumption of PE goat's milkin the year } \\
\text { prior }\end{array}$ & $-0,008766$ & 0,004386 \\
\hline & Coefficient of Determination & 0,91345 & \\
\hline & F-Statistics & 77,8459 & \\
\hline
\end{tabular}

Source: Analysis of Primary Data, 2021 


\section{Analysis of Demand and Supply of PE Goat Milk in DIY}

Supply and demand is an analytical technique that allows researchers to systematically discuss variables that are believed to be relevant to a particular problem. In addition, it can effectively use its limited resources to get a fairly accurate answer.

\section{Analysis of Factors Affecting DIY PE Goat Milk Supply}

Based on the results of the analysis of the supply of PE goat milk using the Equation Model below, it can be obtained results as seen in table 2 .

Equation model:

\section{QS = f (PROD, POP ,HSK , JKM, JKK , PROD $\mathrm{T}-1)$}

In order to simplify the estimation of the equation, the equation is changed in the following form:

\section{$\operatorname{LnQS}=\beta_{0}+\beta_{1} \ln \mathrm{PROD}+\beta_{2} \ln \mathrm{POP}+\beta_{3} \ln H S K+\beta_{4} \ln \mathrm{JKM}+\beta_{5} \ln \mathrm{JKK}+\beta_{6} \ln$ PROD $_{\mathrm{T}-1}+\mathrm{e}$}

Note:

QS =PEGoatMilkSupply (Liters)

$\beta_{0}=$ Constance $/$ intercept

$\beta_{1}-\beta_{6}=$ Regression coefficient of each variable PROD

$=$ PEGoatMilkProduction inDIY(Tons/Year) POP $=\mathrm{PE}$

Goat Population in DIY (Heads/Year) HSK = PE Goat

Milk Price (Rp/liters)

$\mathrm{JKM}=$ NumberofPE Goats enteringDIY(Heads/Year)

JKK = Number of PEGoats exiting DIY (Heads/Year)

PROD $_{\text {T-1 }}$ PE Goat Milk Production in the year prior

Table 2. Analysis of Goat Milk Supply Factors

\begin{tabular}{|c|c|c|c|}
\hline Variable & Parameter & Coefficient & Probability \\
\hline $\mathrm{C}$ & Constance & 45,49932 & 0,1307 \\
\hline PROD & PE Goat Milk Production & 0,904300 & $0,0461^{* * *}$ \\
\hline POP & PE goat population & 0,441698 & $0,0152^{* * *}$ \\
\hline HSK & PE goat milk price & $-0,131043$ & 0,1259 \\
\hline JKM & Number of PE Goats Entring DIY & 0,099391 & 0,8316 \\
\hline JKK & Number of goats Exiting DIY & $-1,270304$ & 0,5645 \\
\hline PROD $_{\mathrm{T}-1}$ & $\begin{array}{l}\text { PEGoatMilkProductionin The } \\
\text { Year Prior }\end{array}$ & 0,833622 & $0,0028^{* * *}$ \\
\hline
\end{tabular}

Source: Analysis of Primary Data, 2021 


$\mathrm{R}^{2} \quad=0,878897$

$\mathrm{R}^{2}$ Adjusted $=0,832677$

FStatistic $=20,2145$

DW $\quad=2,2123$

* $\quad=$ Significant $(\alpha=10 \%)$

** $\quad=$ Significant $(\alpha=5 \%)$

*** $\quad=$ Significant $(\alpha=1 \%)$

Based on table 2, it is shown that the factors influencing the supply of goat's milk are the amount of PE goat's milk production, Total PE goat population, and PE goat's milk production in the year prior.

\section{Analysis of Factors Affecting the Demand for PE Goat Milk in DIY}

Based on the analysis of the demand for PEgoat milk using the Equation Model

Below, it can be obtained results as seen in table 3 .

PE Goat Milk Demand Equation Model:

$\mathrm{QD}=\mathrm{f}\left(\right.$ KONS, JPEND ,PKAP , HSK, HSS , KONS $\left.{ }_{\mathrm{T}-1}\right)$

In order to simplify the estimation of the equation, the equation is changed in the form as follows:

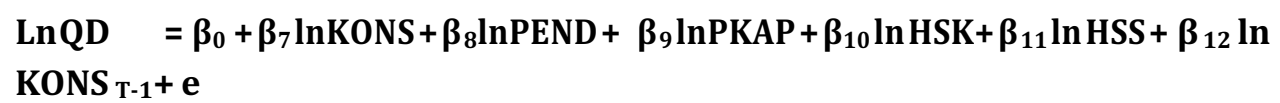

Note:

$\mathrm{QD}=\mathrm{PE}$ Goat Milk Demand/consumption(Liters) $ß_{0}$

$=$ Constance $/$ intercept

$\beta_{7}-\beta_{12}=$ Regression coefficient of each variable

KONS = PE Goat Milk Consumption in DIY (Liters/capita/Year)

PEND $=$ DIY's Population (Inhabitant $/$ Year)

PKAP = Income per capita ( Rp/Year)

HSK = PE Goat Milk Price (Rp/liters)

HSS = DIY'sCow MilkPrice (Rp/liters)

KONS $_{\text {T-1 }}=$ Consumption of PE Goat's Milk in the year prior (Liters/Capita/Year) 
Table 3. Analysis of Goat Milk Demand Factors

\begin{tabular}{|c|c|c|c|}
\hline Variable & Parameter & Coefficient & Probability \\
\hline C & Constance & 55,49932 & 0,1188 \\
\hline KONS & Consumption of PEGoat's Milk & 0,894100 & 0,1261 \\
\hline PKAP & DIY's Population & $-4,320371$ & $0,0253^{* * *}$ \\
\hline HSK & PE goat milk price & 0,039391 & $0,0316^{* * *}$ \\
\hline HSS & Cow's Milk Price & $-1,270304$ & 0,1645 \\
\hline KONS & Consumption of PE Goat's Milk & 0,833622 & $0,0028^{* * *}$ \\
\hline
\end{tabular}

Source: Analysis of Primary Data, 2021

$\mathrm{R}^{2} \quad=0,81457$

$\mathrm{R}^{2}$ Adjusted $=0,80569$

F Statistic $=14,9898$

DW $\quad=2,248123$

** $\quad=$ Significant $(\alpha=5 \%)$

*** $\quad=$ Significant $(\alpha=1 \%)$

Based on table 3, it shows that the factors that influence the demand for goat's milk are the population of DIY, the amount of income per capita of DIY, the price of PE goat's milk, and the amount of consumption of PE goat's milk in the year prior.

\section{DISCUSSION}

Factors that influence the supply of PE goat milk in DIY during the period 2013-2020 are the total population of PE goats, the amount of PE goat milk production and the amount of goat milk production in the year prior. Based on that information's, the increase in the population of PE goats in DIY needs to be developed. Besides looking for superior seeds, especially good male seeds are sought, so that good and superior offspring can be obtained. Another way to increase PE goat's population is to find and develop superior goat breeding technology. Especially local superior seeds from all regions in DIY. Another thing that can be done is the PE goat competition in DIY which is carried out continuously so that regional superior seeds can be identified and can facilitate the selection of goats so that in the future superior beet seeds can be obtained inDIY.

On the Demand side, the factors that influence the demand for PE Goat Milk are the population of DIY, the income per capita of the population of DIY, the price of PE goat's milk and consumption of goat's milk in the previous year. This is understandable because the higher the population, the higher the demand for food, including milk. Likewise, the higher the per capita income, the more people will look for higher quality products.

There are many potential areas in DIY, especially mountainous areas on the north side that need to be developed as production centers for breeding PE crossbreeds and developing agro-industrial 
centers for processing PE goat's milk. Regional centers that have the potential are areas in Pakem and Turi sub-districts, where there are already several groups of independent breeders who have succeeded in processing goat's milk and can be marketed outside the Sleman area, outside the DIY Province and some have even exported to Malaysia, Singapore and United Arab Emirates

\section{CONCLUSION AND AND FURTHER RESEARCH}

Based on the results of the research described above, some conclusions and policies that can be drawn include:

a. The supply condition of PE goat milk in DIY is influenced by the total population of PE goats, total production of PE goat milk and total production of PE goat milk in the year prior.

b. Demand for PE goat milk in DIY is influenced by the population of DIY, income per capita of DIY, price of PE goat milk and consumption of PE goat milk in the year prior.

c. Dairy business actors are expected to carry out a more massive market penetration strategy and market development strategy so that the sales of their products will increase.

d. The government needs to support the movement for obtaining superior PE goat seeds by having collaboration with Universities and Breeding Research institutions or Livestock Research and Development Centre's also embracing the private sector in marketing these superior products from the northern region ofDIY.

e. Further research needs to be done in terms of mapping the potential of goats in DIY, because apart from the price of goat's milk, $\mathrm{PE}$ is promising and its market share is still wide open.

\section{REFERENCE}

David, F.R. 2010. Manajemen Strategis Konsep Edisi Kedua Belas Buku Satu. Jakarta: Salemba Empat. 600 hlm.

Dewi, R. (2018). Analisis Kandungan Zat Gizi Dan Total Uji Cemaran Susu Kambing Peranakan Etawah Yang Dikonsumsi Oleh Ibu Hamil Dan Anak - Anak. Media Farmasi, 14(1), 71. https://doi.org/10.32382/mf.v14i1.73

Dinas Pertanian Kabupaten Sleman.2020. Perkembangan Ternak Kabupaten Sleman. Unpublised report. Febrina, NYT; Syamsul Bahri, Rasmi,DAC. 2019.Susu Segar Kambing Etawa yang difermentasi dalam bambu Betung (Dendrocalamus Asper) Dan Bambu Tali (Gigantochloa Apus) Sebagai Probiotik Bakteri Asam Laktat.Jurnal Pijar MIPA. Universitas Mataram Nusa Tenggara Barat. ISS

Hanafi, F. I., Daris, E., \& Rochaeni, S. (2014). Analisis Faktor-Faktor yang Mempengaruhi Permintaan Tempe di Kelurahan Jurangmangu Timur, Pondok Aren, Tangerang Selatan. Agribusiness Journal, $8(1), 45-58$.

Ischak, Haidar, Suprapti Supardi, and Minar Ferichani. 2018. "Strategi Pemasaran Susu Kambing Di Adilla Goat Farm Desa Jeruksawit Kecamatan Gondangrejo Kabupaten Karanganyar." SEPA: Jurnal Sosial Ekonomi Pertanian dan Agribisnis 14(1): 39.

Isman, F., \& Abubakar Hamzah, R. M. (2014). Analisis Permintaan Telur Ayam di Provinsi Aceh. Jurnal Ilmu Ekonomi: Program Pascasarjana Unsyiah, 2(2).

Kerlinger, 2007. Metode Penelitian Behavioral. Gadjah Mada University Press, Yogyakarta Kotler, Philip dan Gary Amstrong. 2008. Prinsip-Prinsip Pemasaran. Ed 12. Jilid 1. Erlangga: Jakarta.

Lad, Sachin S., K.D. Aparnathi, Bhavbhuti Mehta, and Suresh Velpula. 2017. "Goat Milk in Human Nutrition and Health - A Review.” International Journal of Current Microbiology and Applied Sciences 6(5): 1781-92. 
Factors Affecting Agroindustry Development Etawa (PE) Breeding Goat Milk in Daerah Istimewa Yogyakarta Dwi Aulia Puspitaningrum, Khoirul Hikmah, Adi Ilham

Maesya, A., \& Rusdiana, S. (2018). Prospek Pengembangan Usaha Ternak Kambing dan Memacu $\begin{array}{lllll}\text { Peningkatan Ekonomi } & \text { Peternak. } & \text { Agriekonomika, } & 7(2), & \end{array}$ https://doi.org/10.21107/agriekonomika.v7i2.4459

Mahdiah, Nurlaila. 2020. "Pelatihan Diversifikasi Produk Olahan Susu Di Sentra Peternakan Sapi Perah Kelurahan Kebon Pedes ( Training on Diversification of Processed Dairy Products at the Center for Dairy Farms in Kebon Pedes Village )." Jurnal Pusat Inovasi Masyarakat 2(1): 97-103.

Meutia, N., Rizalsyah, T., Ridha, S., \& Sari, M. K. (2016). Residu Antibiotika Dalam Air Susu Segar yang Berasal Dari Peternakan di Wilayah Aceh Besar ( Antibiotic Residuesin Water Fresh Milk Derivat From Farms in TheTerritory of Aceh Besar ). Ilmu Peternakan, 16(1), 1-5.

Oka, A. Yoeti, 2008. Ekonomi Pariwisata: Introduksi, Informasi, dan Implementasi. Jakarta: Kompas.

Oka, B., Mohammad, Wi., \& Kadirman. (2017). Karakterisasi Kimia Susu Sapi Perah di KAbupaten Sinjai. Jurnal Pendidikan Teknologi Pertanian, 3, 195-202.

Puspitaningrum, DA; Pratiwi ,LL; Suryani, A. 2020. Kajian Spasial dan Nilai Tambah Produk Olahan Susu Kambing Peranakan Etawa (PE) sebagai Pangan Probiotik Guna Peningkatan Imunitas Tubuh di Masa pandemi Corona Virus 19 di Kabupaten Sleman DIY. Laporan Akhir Penelitian Klaster. LPPM UPN Veteran Yogyakarta.

Rangkuti, Freddy. 2001. Analisis SWOT Teknik Membedah Kasus Bisnis. Jakarta: Gramedia Pustaka Utama.

Sartika, W., and J. Hellyward. 2017. "Bauran Pemasaran Susu Sapi Dan Susu Kambing Segar Di Kota Padang." Jurnal Peternakan Indonesia (Indonesian Journal of Animal Science) 19(3): 178.

Wheelen \& Hunger. 2002. Strategic Management and Business Policy. New Jersey: Pearson Prentice Hall 